\title{
POLA PERSEBARAN HOTEL RESROT DI KAWASAN PARIWISATA UBUD
}

\author{
I Putu Hartawan, ST.,MT \\ Program Studi Arsitektur, Fakultas Teknik dan Perencanaan, Universitas Warmadewa \\ Awan1001@gmail.com
}

\begin{abstract}
Abstrak
Perkembangan suatu daerah menjadi kawasan parwisata memberikan pengaruh terhadap, tata ruang, ekonomi, dan kehidupan sosial masyarakat. Hotel adalah salah satu akomodasi wisata yang mememagang peranan penting pada daerah wisata. Ubud terkenal dengan keunikan seni dan budaya yang menyatu dalam kehidupan sehari-hari masyarakatnya. Perkembangan Ubud menjadi daerah tujuan pariwista menyebabkan munculnya akomodasi pariwisata seperti penginapan, restoran, galeri, dan biro perjalanan. Penginapan di kawasan parawista Ubud terbagi mejadi beberapa jenis seperti, homestay, villa, bungalow, dan hotel resort berbintang. Hotel resort merupakan salah satu jenis penginapan yang paling banyak menghabiskan lahan, karena terdapat -fasilitas fasilitas yang ditawarkan. Keberadaan hotel resort berbintang di Kawasan Parawisata Ubud tentu menyumbang pendapatan daerah dan menyediakan lapangan kerja bagi masyarakat sekitar. Selain dampak positif, keberadaan hotel resort juga memberikan dampak negatif, yaitu banyak terdapat ahli fungsi lahan dan kerusakan lingkungan. Peneliti akan melihat secara detail bagaimana pola persebaran hotel resort berbintang di Kawasan Parawisata Ubud dan faktor-faktor yang berpengaruh. Beberapa temuan dalam penelitian ini antara lain, kecendrungan pola persebaran hotel berbintang di Kawasan Pariwisata Ubud berbeda-beda tergantung pada kelasnya, faktor-faktor yang berpengaruh dalam pola persebaran hotel berbintang adalah akses dan potensi pemandangan alam.
\end{abstract}

Kata Kunci: hotel resort, identifikasi, pola persebaran.

\begin{abstract}
The development of an area into a tourist area has an impact on the spatial, economic and social life of the community. Hotel is one of the tourist accommodation which plays an important role in the tourist area. Ubud is famous for its unique arts and culture that are integrated into the daily life of its people. The development of Ubud into a tourism destination has led to the emergence of tourism accommodation such as inns, restaurants, galleries and travel agencies. Lodging in the parawista area of Ubud is divided into several types, such as homestays, villas, bungalows, and star resort hotels. Resort hotels are one of the types of lodging that consume the most land, because there are various facilities offered. The existence of a star resort hotel in the Ubud Tourism Area certainly contributes to regional income and provides employment for the surrounding community. In addition to positive impacts, the existence of resort hotels also has negative impacts, namely there are many experts in land use and environmental damage. Researchers will look in detail at the distribution pattern of star-rated resort hotels in the Ubud Tourism Area and the factors that influence it. Some of the findings in this study include the tendency of the distribution pattern of star hotels in the Ubud Tourism Area to vary depending on the class. The factors that influence the distribution pattern of star hotels are access and potential for natural scenery.
\end{abstract}

Keywords: resort hotel, identification, distribution pattern.

\section{PENDAHULUAN}

Perkembangan suatu daerah menjadi kawasan pirawisata memberikan pengaruh terhadap, tata ruang, ekonomi, dan kehidupan sosial masyarakat. Berbagai macam 
akomodasi wisata bermunculan sebanding dengan tingginya kunjungan wisatawan ke daerah tersebut. Hotel adalah salah satu akomodasi wisata yang mememagang peranan penting pada daerah wisata. Menurut Webster, hotel adalah suatu bangunan atau lembaga yang menyediakan kamar untuk menginap, makanan, dan minuman, serta pelayanan lainnya untuk umum (Fonny, 2008). Terdapat berbagai jenis hotel yang terdapat di Indonesia seperti, city hotel, business hotel, art hotel dan hotel resort. Pada daerah wisata dengan daya tarik keindahan alam atau keunikan budaya pada umumnya terdapat hotel dengan jenis resort.

Ubud adalah sebuah kawasan pariwisata yang terletak di Kabupaten Gianyar, Propensi Bali. Ubud terkenal dengan keunikan seni dan budaya yang menyatu dalam kehidupan sehari-hari masyarakatnya. Seni dan budaya yang tertuang dalam kehidupan ritual beragama masyarakat Ubud. Selain seni dan budaya, Ubud juga mempunyai potensi alam seperti, sawah hijau dan pepohonan yang masih asri di pinggir atau tebing sungai, serta iklim lingkungan perdesaan yang masih asri. Potensi-potensi tersebut menarik minat wisatawan domestik maupun mancanegara untuk datang ke Ubud. Menurut Picard (2006:120), berbeda dengan resort-resort pinggir pantai di Bali, Ubud menarik wisatawan yang lebih melihat Bali dalam citra permukiman perdesaan dengan kehidupan seni dan ritual keagamaan masyarakatnya.

Perkembangan Ubud menjadi kawasan pariwisata tidak lepas dari peranan seniman yang memberi warna baru pada perkembangan seni budaya di Ubud. Nama-nama seperti Walter Spies, Rudolf Bonnet memberikan peran penting dalam perkembangan pariwista Ubud melalui media seni lukis. Perkembangan pariwisata Ubud dimulai pada tahun 1976 ketika listrik mulai masuk desa, kemudian berkembang pesat pada awal tahun 1980-an (Putra, 2014:3). Pada saat itu mulai bermuculan akomodasi pariwisata seperti penginapan, restoran, galeri, dan biro perjalanan. Pada tahun 1994 Ubud telah berkembang, dalam hal ketersediaan akomodasi pariwisata menjadi 2200 kamar dari 450 kamar tahun 1981, atau sekitar 7 persen kapasitas perhotelan di Pulau Bali (Picard, 2006:124). Penginapan di kawasan parawista Ubud terbagi mejadi beberapa jenis yaitu, homestay, villa, bungalo, dan hotel resort berbintang. Ubud bahkan menjadi lokasi dari resort berbintang ternama seperti Ubud Hanging Garden, Four Season, dan Maya Resort and Spa.

Hotel resort merupakan salah satu jenis penginapan yang paling banyak menghabiskan lahan, karena terdapat banyak fasilitas mewah ditawarkan. Hotel resort di Ubud pada umumnya berlokasi pada lahan yang memiliki pemandangan alam indah, misalnya pada tebing di pinggir sungai. Keberadaan hotel resort berbintang di Kawasan Pariwisata Ubud tentu menyumbang pendapatan daerah dan menyediakan lapangan pekerjaan bagi masyarakat sekitar. Selain dampak positif, keberadaan hotel resort juga memberikan dampak negatif, yaitu banyak terdapat ahli fungsi lahan dan kerusakan lingkungan. Couteau (dalam Sukawati, 2004:6) dalam tulisannya mengungkapkan industri pariwisata jelas membawa dampak terhadap sektor agraris, terutama masalah ahli fungsi lahan sebagai upaya untuk memenuhi tuntutan prasarana dan sarana pariwisata.

Dengan demikian hal tersebut sangat menarik untuk diteliti lebih lanjut. Peneliti akan melihat secara detail bagaimana pola persebaran hotel resort berbintang di Kawasan Parawisata Ubud, serta melihat faktor-faktor yang mempengaruhi Sehingga 
nanti dapat diteliti lebih lanjut apa dampak yang ditimbulkan dan apakah memberikan pengaruh yang segnifikan tehadap kemajuan kawasan tersebut. Hasil penelitian ini nantinya juga dapat menjadi faktor pertimbangan dalam membuat tata ruang kawasan pariwisata.

\section{METODE}

Penelitian ini menerapkan metode penelitian kualitatif dengan pendekatan induktif dan menggunakan paradigma naturalistik. Paradigma naturalistik digunakan karena penelitian dilakukan dalam situasi yang wajar sebagaimana mestinya. Metode kualitatif adalah suatu metode yang menekankan kepada tata cara penggunaan alat dan teknik di bidang penelitian yang berorientasi pada paradigma alamiah (Moleong, 1989:124). Pengertian metode kualitatif menurut Bogdan dan Taylor (dalam Moleong, 1989:125), dimaksudkan sebagai prosedur penelitan yang menghasilkan data deskriptif berupa katakata tertulis, gambar atau lisan dari objek yang diamati.

Kasus penelitian adalah hotel resort bintang lima, bintang empat, dan bintang tiga dikawasan Pariwisata Ubud. Jenis data yang dikumpulkan ada dua jenis yaitu data sekunder dan data primer. Data Sekunder bersumber dari dinas setempat berupa data Tanda Daftar Usaha Pariwisata empat tahuh terakhir untuk mengetahui persebaran lokasi hotel berbintang di Kawasan Pariwisata Ubud. Data primer didapat dengan melakukan observasi ke lapangan serta wawancara terhadap pihak manajemen hotel dan Kepala DPMPTSP Kabupaten Gianyar. Kemudian dilakukan dialog antar tema temuan dan juga teori yang relevan dengan topik penelitian, sehingga dapat ditarik kesimpulan.

\section{HASIL DAN PEMBAHASAN}

Pada sub bahasan ini dipaparkan data persebaran hotel bintang lima, bintang empat, dan bintang tiga di Kawasan Pariwisata Ubud. Lebih lanjut dianalisis faktor-faktor yang mempengerahui persebaran hotel tersebut

\section{Hotel Bebintang di Kawasan Pariwisata Ubud}

Hotel berbintang yang terletak dalam Kawasan Pariwisata Ubud. Terdapat dua sumber data yang dapat dipakai acuan untuk menentukan hotel-hotel berbintang di Kawasan Pariwisata Ubud, yaitu data ljin Mendirikan Bangunan (IMB) dan Data Tanda Daftar Usaha Pariwisata (TDUP). Karena data IMB tidak dapat diakses oleh publik, maka digunakan data TDUP untuk menentukan pemetaan hotel berbintang di Kawasan Pariwisata Ubud. Tanda Daftar Usaha Pariwisata juga menandakan hotel-hotel tersebut masih beroprasi, karena tanda daftar usahanya diperpanjang. Data TDUP hotel berbintang periode empat terakhir yaitu 2017-2020 dipakai acuan dalam menentukan jumlah dan lokasi hotel berbintang di Kawasan Pariwisata Ubud, karena TDUP diperpanjang setiap lima tahun sekali. Hotel berbintang yang akan dibahas dalam penelitian ini terdiri dari tiga jenis yaitu, hotel bintang tiga, hotel bintang empat, dan hotel bintang lima. Untuk hotel bintang dua tidak masuk dalam studi kasus penelitian karena jumlahnya sedikit. Untuk lebih jelasanya mengenai data tersebut akan dijelaskan pada sub bahasan berikut. 


\section{Jurnal LANALA}

Volume 9, No. 1 | Februari 2021

\section{A. Hotel Bintang Tiga}

Terdapat beberapa kreteria hotel bintang tiga berdsarkan kajian teori. Jumlah kamar minimal 30 kamar (termasuk minimal 2 suite room, 48m2). Ukuran kamar minimum termasuk kamar mandi 22m2 untuk kamar single dan 26m2 untuk kamar double. Ruang publik luas $3 \mathrm{~m} 2 \times$ jumlah kamar tidur, minimal terdiri dari lobi, ruang makan $(>75 \mathrm{~m} 2)$ dan bar. Pelayanan akomodasi yaitu berupa penitipan barang berharga, penukaran uang asing, postal servis dan antar jemput. Berikut adalah hotel berbintang tiga yang masih beroprasi di Kawasan Pariwisata Ubud berdasarkan tanda daftar usaha pariwisata selama 4 tahun terakhir. Data ini diperoleh dari Dinas Penanaman Modal dan Pelayanan Terpadu Satu Pintu Kabupaten Gianyar.

Tabel 1. Hotel Bintang Tiga di Kawasan Pariwisata Ubud

\begin{tabular}{|c|c|c|c|c|}
\hline NO & NAMA HOTEL & LOKASI & KAPASITAS & KELAS \\
\hline 1 & $\begin{array}{l}\text { Bambu Indah/ CV. Bambu } \\
\text { Indah }\end{array}$ & $\begin{array}{l}\text { Br. Baung, Ds. } \\
\text { Sayan, Ubud }\end{array}$ & 18 kamar & bintang 3 \\
\hline 2 & Cinta Inn & $\begin{array}{l}\text { Jln. Monkey } \\
\text { Forest, Ubud }\end{array}$ & 7 kamar & bintang 3 \\
\hline 3 & Kiskenda Cottage & Jln. Bisma, Ubud & 14 kamar & bintang 3 \\
\hline 4 & Sayan Terace Hotel & $\begin{array}{l}\text { Br. Kutuh, Ds. } \\
\text { Sayan, Ubud }\end{array}$ & 9 kamar & bintang 3 \\
\hline 5 & $\begin{array}{l}\text { Om Ham Retreat / PT. } \\
\text { Om Ham Buana } \\
\text { Jagaddhitam }\end{array}$ & $\begin{array}{l}\text { Br. Junjungan, } \\
\text { Ubud }\end{array}$ & 41 kamar & bintang 3 \\
\hline 6 & Inata Bisma & $\begin{array}{l}\text { Jln. Bisma, Lingk. } \\
\text { Padang Tegal, } \\
\text { Ubud }\end{array}$ & 22 kamar & bintang 3 \\
\hline 7 & Puri Padma & $\begin{array}{l}\text { Jln. Raya } \\
\text { Andong, Br. } \\
\text { Nagi,Petulu }\end{array}$ & 25 kamar & bintang 3 \\
\hline 8 & Nick's Hidden Cottages & Jln. Bisma, Ubud & 15 kamar & bintang 3 \\
\hline 9 & Villa Puri Artha & $\begin{array}{l}\text { Br. Pengosekan } \\
\text { Kaja, Ds. Mas, } \\
\text { Ubud }\end{array}$ & 10 kamar & bintang 3 \\
\hline 10 & $\begin{array}{l}\text { Champlung Sari/PT. Bali } \\
\text { Gema Wisata }\end{array}$ & $\begin{array}{l}\text { JIn. Raya Monkey } \\
\text { Forest, Ubud }\end{array}$ & 94 kamar & bintang 3 \\
\hline 11 & Pertiwi Resort and Spa & $\begin{array}{l}\text { Lingk. Padang } \\
\text { Tegal tengah, } \\
\text { Ubud }\end{array}$ & 80 kamar & bintang 3 \\
\hline 12 & Alam Santi & $\begin{array}{l}\text { Lingk. Nyuh } \\
\text { Kuning, Mas, } \\
\text { Ubud }\end{array}$ & 10 kamar & bintang 3 \\
\hline 13 & The Sunti Ubud & $\begin{array}{l}\text { Jln. Raya } \\
\text { Pengosekan, Br. } \\
\text { Pengosekan } \\
\text { Kaja, Mas, Ubud }\end{array}$ & 52 kamar & bintang 3 \\
\hline
\end{tabular}


Volume 9, No. 1 | Februari 2021

\begin{tabular}{|c|c|c|c|c|}
\hline 14 & Pertiwi Bisma I & $\begin{array}{l}\text { Jln. Bisma, Lingk. } \\
\text { Padang Tegal } \\
\text { Tengah, Ubud }\end{array}$ & 20 kamar & bintang 3 \\
\hline 15 & Munari & $\begin{array}{l}\text { Jln. Raya } \\
\text { sanggingan, } \\
\text { kedewatan, ubud }\end{array}$ & 8 kamar & bintang 3 \\
\hline 16 & Cendana Cottages & $\begin{array}{l}\text { Lingk. Padang } \\
\text { Tegal tengah, } \\
\text { Ubud }\end{array}$ & 10 kamar & bintang 3 \\
\hline 17 & Bliss Bungalow & $\begin{array}{l}\text { Br. Lungsiakan, } \\
\text { Kedewatan, Ubud }\end{array}$ & 20 kamar & bintang 3 \\
\hline 18 & $\begin{array}{l}\text { Artini } 3 \text { Cottages / } \\
\text { Warisan Artini Mandiri }\end{array}$ & $\begin{array}{l}\text { Br. Tengah Kauh, } \\
\text { Peliatan,, Ubud }\end{array}$ & 39 kamar & bintang 3 \\
\hline 19 & $\begin{array}{l}\text { " Kori Ubud Resort " CV. } \\
\text { Kori Ubud Resort }\end{array}$ & $\begin{array}{l}\text { Jl. Raya } \\
\text { Sanggingan, Br. } \\
\text { Lungsiakan, } \\
\text { Kedewatan, Ubud }\end{array}$ & & bintang 3 \\
\hline 20 & $\begin{array}{l}\text { Hotel Royal Pandawa } \\
\text { Maxone }\end{array}$ & $\begin{array}{l}\text { Br. Pengosekan } \\
\text { Kaja, Ds. Mas, } \\
\text { Ubud }\end{array}$ & & bintang 3 \\
\hline 21 & Inata Hotel & $\begin{array}{l}\text { Jl. Monkey } \\
\text { Forest, Br. } \\
\text { Padangtegal } \\
\text { Kelod, Ubud }\end{array}$ & & bintang 3 \\
\hline 22 & Tetirah & $\begin{array}{l}\text { Jl. Suweta, Br. } \\
\text { Bentuyung, Sakti, } \\
\text { Ubud }\end{array}$ & & bintang 3 \\
\hline 23 & $\begin{array}{l}\text { Junjungan Ubud Hotel \& } \\
\text { Spa/PT. Bali Satu }\end{array}$ & $\begin{array}{l}\text { Jln. Tirta Tawar } \\
\text { Km.35, } \\
\text { Junjungan,Ubud }\end{array}$ & & bintang 3 \\
\hline 24 & Bhuwana Ubud & $\begin{array}{l}\text { Jln. Raya } \\
\text { Kumbuh, Br. } \\
\text { Kumbuh, Ds. } \\
\text { Mas, Ubud }\end{array}$ & & bintang 3 \\
\hline 25 & $\begin{array}{l}\text { Y - Resort / PT. Tri } \\
\text { Dharma Dewata }\end{array}$ & $\begin{array}{l}\text { Br. Penestanan } \\
\text { Kelod,Ds. Sayan, } \\
\text { Ubud }\end{array}$ & & bintang 3 \\
\hline 26 & Jati Cottages & $\begin{array}{l}\text { Jln. Jatayu, Br. } \\
\text { Tebesaya, } \\
\text { Peliatan, Ubud }\end{array}$ & & bintang 3 \\
\hline 27 & $\begin{array}{l}\text { Hotel Puri Artha/ PT. Puri } \\
\text { Artha Hotel Development }\end{array}$ & $\begin{array}{l}\text { Jln. Md Lebah, } \\
\text { Br. Kalah, Ds. } \\
\text { Peliatan, Ubud }\end{array}$ & & bintang 3 \\
\hline 28 & Tjampuhan & $\begin{array}{l}\text { Jln. Raya } \\
\text { Campuhan, Ubud }\end{array}$ & & bintang 3 \\
\hline 29 & $\begin{array}{l}\text { Rama Phala Resort dan } \\
\text { Restoran / PT. Rupaka } \\
\text { Phala Catula }\end{array}$ & $\begin{array}{l}\text { Jln. Hanoman, } \\
\text { Lingk. Padang } \\
\text { Tegal, Ubud }\end{array}$ & & bintang 3 \\
\hline 30 & $\begin{array}{l}\text { Radha Phala Resort \& } \\
\text { Spa / PT. Rupaka Phala } \\
\text { Catula }\end{array}$ & $\begin{array}{l}\text { Jln. Hanoman, } \\
\text { Lingk. Padang } \\
\text { Tegal, Ubud }\end{array}$ & & bintang 3 \\
\hline
\end{tabular}

Sumber : DPMSPT Kabupaten Gianyar 
Pada periode tahun 2017-2020 terdapat 30 hotel bintang tiga yang memperpanjang tanda daftar usaha pariwisata di Kawasan Pariwisata Ubud. Dalam kajian pustaka dijelaskan hotel bintang tiga minimal mempunyai jumlah kamar sebanyak 30 kamar, tetapi sebagian besar hotel bintang tiga yang terdapat di Kawasan Pariwsata Ubud memiliki jumlah kamar kurang dari 30 kamar. Tipe hotel bintang tiga di Kawasan Pariwsata Ubud adalah hotel resort untuk wisatawan yang ingin berlibur menikmati suasana alam dan keunikan budaya masyarakat Ubud.

\section{B. Hotel Bintang Empat}

Hotel bintang empat memiliki beberapa persyaratan yang lebih tinggi dari hotel bintang tiga, baik secara kapasitas dan fasilitas. Jumlah kamar minimal 50 kamar (termasuk minimal 3 suite room, $48 \mathrm{~m} 2$ ). Pelayanan akomodasi yaitu berupa penitipan barang berharga, penukaran uang asing, postal servis dan antar jemput. Fasilitas tambahan lain berupa pertokoan, kantor biro perjalanan, maskapai perjalanan, salon, function room, banquet hall, serta fasilitas olahraga dan sauna. Ditinjau dari jumlah kamarnya, hotel bintang empat yang terdapat di Kawasan Pariwisata Ubud sebagian besar memiliki jumlah kamar kurang dari 50 kamar. Fasilitas yang ditawarkan hotel bintang empat di Kawasan Pariwisata Ubud sudah sesuai dengan standar hotel bintang empat pada kajian teori. Berikut ini adalah hotel bintang empat yang masih beroprasi di Kawasan Pariwisata Ubud berdasarkan tanda daftar usaha pariwisata selama periode empat tahun terakhir (2017-2020). Data ini diperoleh dari Dinas Penanaman Modal dan Pelayanan Terpadu Satu Pintu Kabupaten Gianyar.

Tabel 2. Hotel Bintang Empat di Kawasan Pariwisata Ubud

\begin{tabular}{|c|c|c|c|c|}
\hline NO & NAMA HOTEL & LOKASI & KAPASITAS & KELAS \\
\hline 1 & $\begin{array}{l}\text { Vajra Vajra / PT. } \\
\text { Vajra }\end{array}$ & $\begin{array}{l}\text { Br. Triwangsa, Ds. Sebali, } \\
\text { Keliki, Tegallalang }\end{array}$ & 8 kamar & bintang 4 \\
\hline 2 & $\begin{array}{l}\text { Tejaprana Bisma } \\
\text { (PT. Abirupa Nusa } \\
\text { Cipta) }\end{array}$ & $\begin{array}{l}\text { Jl. Suweta, Br. Bentuyung, } \\
\text { Sakti, Ubud }\end{array}$ & 26 kamar & bintang 4 \\
\hline 3 & Sankara Resort & $\begin{array}{l}\text { Jln. Nyuh Kuning,Br. } \\
\text { Pengosekan, Ds. } \\
\text { Mas,ubud }\end{array}$ & 30 kamar & bintang 4 \\
\hline 4 & $\begin{array}{l}\text { Tanah Merah } \\
\text { Resort }\end{array}$ & Pejeng Kaja & & bintang 4 \\
\hline 5 & Temuku Ubud Villas & $\begin{array}{l}\text { Br. Ayah,Kelusa, } \\
\text { Payangan }\end{array}$ & 11 kamar & bintang 4 \\
\hline 6 & $\begin{array}{l}\text { The Sungu Resort \& } \\
\text { Spa / PT. Villa Citra } \\
\text { Padma Resor }\end{array}$ & $\begin{array}{l}\text { Jln. Hanoman, Lingk. } \\
\text { Padang Tegal Kelod, } \\
\text { Ubud }\end{array}$ & 10 kamar & bintang 4 \\
\hline
\end{tabular}


Jurnal LNALC.

Volume 9, No. 1 | Februari 2021

\begin{tabular}{|c|c|c|c|c|}
\hline 7 & $\begin{array}{l}\text { Puri Sunia Resort / } \\
\text { PT. Garuda } \\
\text { Majakara Semesta }\end{array}$ & Br. Abangan, Tegallalang & $\begin{array}{l}30 \text { tempat } \\
\text { duduk }\end{array}$ & bintang 4 \\
\hline 8 & Komaneka Bisma & Jln. Bisma, Ubud & 30 kamar & bintang 4 \\
\hline 9 & $\begin{array}{l}\text { Ubud Padi Villas / } \\
\text { CV. Padi Indah }\end{array}$ & $\begin{array}{l}\text { Br. Lungsiakan, } \\
\text { Kedewatan, Ubud }\end{array}$ & 14 kamar & bintang 4 \\
\hline 10 & $\begin{array}{l}\text { Ashoka Tree Resort } \\
\text { / PT. Bali Rich } \\
\text { Mandiri } \\
\end{array}$ & $\begin{array}{l}\text { Br. Tanggayuda, Ds. } \\
\text { Kedewatan, Ubud }\end{array}$ & 45 kamar & bintang 4 \\
\hline 11 & $\begin{array}{l}\text { Wapa Di Uma / PT. } \\
\text { Wapa Di Uma }\end{array}$ & $\begin{array}{l}\text { Jln. Suweta, Br. } \\
\text { Bentuyung, Ubud }\end{array}$ & & bintang 4 \\
\hline 12 & Haniman Hotel & $\begin{array}{l}\text { Jln. Jatayu, Lingk. Padang } \\
\text { Tegal, Ubud }\end{array}$ & 20 kamar & bintang 4 \\
\hline 13 & $\begin{array}{l}\text { Dedari Kendran } \\
\text { Villa / } \\
\text { CV. Dedari } \\
\text { Kriyamaha Villa } \\
\end{array}$ & $\begin{array}{l}\text { Br. Pinjul, Ds. Kendran, } \\
\text { Tegallalang }\end{array}$ & 16 kamar & bintang 4 \\
\hline 14 & Bagus Jati & $\begin{array}{l}\text { Br. Jati, Ds. Sebatu, } \\
\text { Tegallalang }\end{array}$ & 18 kamar & bintang 4 \\
\hline 15 & $\begin{array}{l}\text { Anulekha Private } \\
\text { Residence / PT. } \\
\text { Anulekha bali }\end{array}$ & $\begin{array}{l}\text { Br. Silungan, Ds. } \\
\text { Lodtunduh, Ubud }\end{array}$ & 25 kamar & bintang 4 \\
\hline 16 & Sativas Villas & Lingk. Tegallantang, Ubud & & bintang 4 \\
\hline 17 & Abing Terrace Ubud & $\begin{array}{l}\text { Jl. Sri Wedari, Lingk. } \\
\text { Tegallantang, Ubud }\end{array}$ & & bintang 4 \\
\hline 18 & $\begin{array}{l}\text { " Udaya Resort \& } \\
\text { Spa " PT. Ahayu } \\
\text { Arunima Udaya }\end{array}$ & Lingk. Tegallantang, Ubud & & bintang 4 \\
\hline 19 & $\begin{array}{l}\text { Hotel Element By } \\
\text { Westin / PT.Makmur } \\
\text { Berkah Amanda } \\
\text { Hotel }\end{array}$ & $\begin{array}{l}\text { Jl. Raya Andong, Petulu, } \\
\text { Ubud }\end{array}$ & & bintang 4 \\
\hline 20 & $\begin{array}{l}\text { The Ubud Village } \\
\text { Resort/CV. Ubud } \\
\text { Village } \\
\end{array}$ & $\begin{array}{l}\text { Jln. Wanara Wana, Br. } \\
\text { Pengosekan, Ds. Mas, } \\
\text { Ubud }\end{array}$ & & bintang 4 \\
\hline 21 & \begin{tabular}{|l|} 
The Origin \\
hotel/Pt.Awan \\
Jingga Ubud \\
\end{tabular} & $\begin{array}{l}\text { Jln. Tirta Tawar, Br. Kutuh } \\
\text { Kelod, DS. Petulu,Ubud }\end{array}$ & & bintang 4 \\
\hline 22 & $\begin{array}{l}\text { Ulun Ubud Resort \& } \\
\text { Spa }\end{array}$ & $\begin{array}{l}\text { Jln. Raya Sanggingan, Br. } \\
\text { Lungsiakan, Ubud }\end{array}$ & & bintang 4 \\
\hline 23 & $\begin{array}{l}\text { Hotel Seres Spring } \\
\text { Resort \& Spa } \\
\text { Conference / PT. } \\
\text { Sutera Sejahtera }\end{array}$ & $\begin{array}{l}\text { Br. Jukut Paku, Ds. } \\
\text { Singakerta, Ubud }\end{array}$ & & bintang 4 \\
\hline 24 & $\begin{array}{l}\text { Hotel Best Western/ } \\
\text { PT. Sarana Wisata } \\
\text { Agung }\end{array}$ & Lingk. Taman Kaja, Ubud & & bintang 4 \\
\hline 25 & $\begin{array}{l}\text { Villa Alam Ubud / } \\
\text { PT. Alam Ubud } \\
\text { Resident }\end{array}$ & $\begin{array}{l}\text { Br. Tengah, Kendran, } \\
\text { Tegallalang }\end{array}$ & & bintang 4 \\
\hline
\end{tabular}




\section{Jurnal AMALA}

Volume 9, No. 1 | Februari 2021

\begin{tabular}{|c|l|l|l|l|}
26 & $\begin{array}{l}\text { Royal Casa } \\
\text { Ganesha/PT. PHR } \\
\text { Puri Pratama }\end{array}$ & $\begin{array}{l}\text { Br. Kelingkung, Ds. } \\
\text { Lodtunduh, Ubud }\end{array}$ & bintang 4 \\
\hline 27 & $\begin{array}{l}\text { Natura Resort and } \\
\text { Spa }\end{array}$ & $\begin{array}{l}\text { Banjar Laplapan Jl. Raya } \\
\text { Laplapan, Petulu, } \\
\text { Kecamatan Ubud, } \\
\text { Kabupaten Gianyar }\end{array}$ & bintang 4 \\
\hline
\end{tabular}

Sumber : DPMSPT Kabupaten Gianyar

Dari tahun 2017-2020 terdapat 27 hotel bintang empat yang memperpanjang tanda daftar usaha di Kawasan Pariwisata Ubud. Ditinjau dari jumlah kamarnya hotel bintang empat di Kawasan Pariwisata Ubud sebagian besar kurang dari 50 kamar. Dilihat dari segi fasilitas yang ditawarkan hotel bintang empat di Ubud sudah melebihi dari standar yang sudah ditetapkan. Hotel bintang empat di Kawasan Pariwisata Ubud diperuntukkan bagi wisatawan yang sedang mengadakan wisata dan liburan. Hotel bintang empat di Ubud mengandalkan potensi alam berupa pemandangan alam yang indah dan taman buatan untuk menarik pengunjung.

\section{Hotel Bintang Lima}

Hotel bintang lima memiliki standar paling tinggi. Jumlah kamar minimal 100 kamar (termasuk mminimal 4 suite room, 58m2). Pelayanan akomodasi yaitu berupa penitipan barang berharga, penukaran uang asing, postal servis dan antar jemput. Terdapat juga fasilitas tambahan seperti, pertokoan, kantor biro perjalanan, maskapai perjalanan, drugstore, salon, function room, banquet hall, serta fasilitas olahraaga dan sauna. Ditinjau dari jumlah kamar hotel bintang lima yang terdapat di Kawasan Pariwisata Ubud sebagian besar memiliki jumlah kamar kurang dari 100 kamar. Fasilitas yang ditawarkan hotel bintang lima di Kawasan Pariwisata Ubud sudah sesuai dengan standar hotel bintang lima. Berikut adalah hotel bintang lima yang masih beroprasi di Kawasan Pariwisata Ubud berdasarkan tanda daftar usaha pariwisata selama 4 tahun terakhir (2017-2020). Data ini diperoleh dari Dinas Penanaman Modal dan Pelayanan Terpadu Satu Pintu Kabupaten Gianyar.

Tabel 3. Hotel bintang lima di Kawasan Pariwisata Ubud

\begin{tabular}{|c|l|l|l|l|}
\hline NO & \multicolumn{1}{|c|}{ NAMA HOTEL } & \multicolumn{1}{|c|}{ LOKASI } & KAPASITAS & KELAS \\
\hline 1 & $\begin{array}{l}\text { Mandapa A Ritz Carlton } \\
\text { Reserve/PT. Sukses } \\
\text { Primatama Bersama }\end{array}$ & $\begin{array}{l}\text { Jln. Kedewatan, Br. } \\
\text { Kedewatan, Ubud }\end{array}$ & 60 kamar & bintang 5 \\
\hline 2 & $\begin{array}{l}\text { Ayung Resort Ubud / } \\
\text { PT. Banyu Mas } \\
\text { Sembada }\end{array}$ & $\begin{array}{l}\text { Br. Begawan, Ds. } \\
\text { Melinggih Kelod, } \\
\text { Payangan }\end{array}$ & 114 kamar & bintang 5 \\
\hline 3 & $\begin{array}{l}\text { Puri Wulandari A } \\
\text { Boutique Resort \& Spa / } \\
\text { PT. Transindo Equatorial }\end{array}$ & $\begin{array}{l}\text { Br. Tanggayuda, } \\
\text { Ds. Kedewatan, } \\
\text { Ubud }\end{array}$ & 35 kamar & bintang 5 \\
\hline
\end{tabular}


Volume 9, No. 1 | Februari 2021

\begin{tabular}{|c|c|c|c|c|}
\hline 4 & $\begin{array}{l}\text { The Garcia Ubud / PT. } \\
\text { Puri Menggah Wisata }\end{array}$ & $\begin{array}{l}\text { Jln. Raya Silungan, } \\
\text { Lodtunduh, Ubud }\end{array}$ & 61 kamar & bintang 5 \\
\hline 5 & $\begin{array}{l}\text { Maya Ubud Resort \& } \\
\text { Spa ( PT. Hotel Pandan } \\
\text { Arum ) }\end{array}$ & $\begin{array}{l}\text { Jln. Gunung Sari, } \\
\text { Ds. Peliatan, Ubud }\end{array}$ & 108 kamar & bintang 5 \\
\hline 6 & $\begin{array}{l}\text { KAMANDALU Resort \& } \\
\text { Spa,PT. Puri Kamandalu }\end{array}$ & $\begin{array}{l}\text { Jln. Raya Andong, } \\
\text { Br. Nagi,Petulu, } \\
\text { Ubud }\end{array}$ & 56 kamar & bintang 5 \\
\hline 7 & Amandari / PT. Villa Ayu & $\begin{array}{l}\text { Jln. Raya } \\
\text { Kedewatan, Ubud }\end{array}$ & 31 kamar & bintang 5 \\
\hline 8 & $\begin{array}{l}\text { Tanadewa Ubud/PT. } \\
\text { Bumi Pesona Mandiri }\end{array}$ & $\begin{array}{l}\text { Br. Kengetan, } \\
\text { Singakerta, Ubud }\end{array}$ & 41 kamar & bintang 5 \\
\hline 9 & $\begin{array}{l}\text { The Royal Pita Maha/ } \\
\text { PT. Puri Tjampuhan } \\
\text { Agung }\end{array}$ & $\begin{array}{l}\text { Jln. Raya, } \\
\text { Kedewatan, Ubud }\end{array}$ & 52 kamar & bintang 5 \\
\hline 10 & Kuwarasan & $\begin{array}{l}\text { Jln. Cinta, Br. } \\
\text { Penusuan, } \\
\text { Tegallalang }\end{array}$ & 27 kamar & bintang 5 \\
\hline 11 & Komaneka & $\begin{array}{l}\text { Jln. Monkey Forest, } \\
\text { Ubud }\end{array}$ & 14 kamar & bintang 5 \\
\hline 12 & $\begin{array}{l}\text { Komaneka Hotel } \\
\text { Tanggayuda }\end{array}$ & $\begin{array}{l}\text { Br. Tanggayuda, } \\
\text { kedewatan, ubud }\end{array}$ & 21 kamar & bintang 5 \\
\hline 13 & $\begin{array}{l}\text { Royal Kamuela/PT. } \\
\text { Cipta Satya Graha }\end{array}$ & $\begin{array}{l}\text { Jln. Monkey Forest, } \\
\text { Lingk padang tegal, } \\
\text { Ubud }\end{array}$ & 12 kamar & bintang 5 \\
\hline 14 & Natya Resort Ubud & $\begin{array}{l}\text { Br. Kelabang } \\
\text { Moding, Tegallalang }\end{array}$ & 24 kamar & bintang 5 \\
\hline 15 & The Kayon & Br. Triwangsa Keliki & 24 kamar & bintang 5 \\
\hline 16 & $\begin{array}{l}\text { Kayumanis Ubud Private } \\
\text { \& Spa/PT. Kirana } \\
\text { Property }\end{array}$ & $\begin{array}{l}\text { Br. Baung, Ds. } \\
\text { Sayan, Ubud }\end{array}$ & 23 kamar & bintang 5 \\
\hline 17 & $\begin{array}{l}\text { "Hotel Visesa Resort \& } \\
\text { Villa Ubud " PT. } \\
\text { Bhavana Ultimate } \\
\text { Development }\end{array}$ & $\begin{array}{l}\text { Jl. Suweta, Br. } \\
\text { Bentuyung, Sakti, } \\
\text { Ubud }\end{array}$ & & bintang 5 \\
\hline 18 & $\begin{array}{l}\text { Hotel Suarti Grand } \\
\text { Village }\end{array}$ & $\begin{array}{l}\text { Jln. Nyuh } \\
\text { Kuning,Br. } \\
\text { Pengosekan, Ds. } \\
\text { Mas,ubud } \\
\end{array}$ & & bintang 5 \\
\hline 19 & $\begin{array}{l}\text { Alila Ubud/PT. Bukit } \\
\text { Uluwatu Villa }\end{array}$ & $\begin{array}{l}\text { Ds.Melinggih Kelod, } \\
\text { Payangan }\end{array}$ & & bintang 5 \\
\hline 20 & $\begin{array}{l}\text { Samsara Ubud/PT. } \\
\text { Samsara Raga } \\
\text { International }\end{array}$ & $\begin{array}{l}\text { Br. Ayah,Kelusa, } \\
\text { Payangan }\end{array}$ & & bintang 5 \\
\hline 21 & $\begin{array}{l}\text { Hotel Alaya Resort Ubud } \\
\text { / PT. Alaya Resort }\end{array}$ & $\begin{array}{l}\text { Jln. Hanoman, } \\
\text { Lingk. Padang } \\
\text { Tegal Kelod, Ubud }\end{array}$ & & bintang 5 \\
\hline
\end{tabular}




\begin{tabular}{|l|l|l|l|l|}
\hline 22 & Four Season & $\begin{array}{l}\text { Jl. Raya Sayan } \\
\text { No.29, Sayan, } \\
\text { Kecamatan Ubud, } \\
\text { Kabupaten Gianyar }\end{array}$ & & bintang 5 \\
\hline
\end{tabular}

Sumber : DPMSPT Kabupaten Gianyar

Dari tahun 2017-2020 terdapat 22 hotel bintang lima yang memperpanjang tanda daftar usaha di Kawasan Pariwisata Ubud. Hotel bintang lima mempunyai fasilitas mewah terlengkap diperuntukkan bagi wisatawan yang sedang mengadakan wisata dan liburan dengan tingkat ketenangan paling tinggi. Hotel bintang lima di Ubud mengandalkan potensi alam berupa pemandangan yang indah untuk menarik pengunjung selain berbagai fasilitas mewahnya. Pemandangan yang ditawarkan hotel di Kawasan ini berupa hutang tebing sungai dan persawahan.

\section{Identifikasi Pola Persebaran Hotel Berbintang di Kawasan Pariwisata Ubud}

Pada bagian ini dilakukan identifikasi pola persebaran hotel berbintang di Kawasan Pariwisata Ubud. Lebih lanjut akan dianalisis bagaimana kecendrungan pola persebaran hotel bintang lima, bintang empat, dan bintang tiga. Apa saja faktor-faktor yang mempengaruhi pola persebaran hotel berbintang tersebut. Berdasarkan data yang diperoleh dari Dinas Penanaman Modal dan Pelayanan Terpadu Satu Pintu Kabupaten Gianyar selama empat tahun terakhir (2017-2020), terdapat 79 hotel berbintang yang memperpanjang atau membuat baru tanda daftar usaha pariwisata. Hotel tersebut terdiri dari 22 hotel bintang lima, 27 hotel bintang empat, dan 30 hotel bintang tiga. Jadi hotel yang paling banyak dalam periode tersebut adalah hotel bintang tiga, di urutan kedua terbanyak adalah hotel bintang empat dan yang paling sedikit adalah hotel bintang lima. Untuk lebih jelasnya tentang jumlah hotel berbintang di Kawasan Pariwisata Ubud dapat dilihat pada diagram berikut.

\section{Hotel Berbintang di Kawasan Pariwisata Ubud}

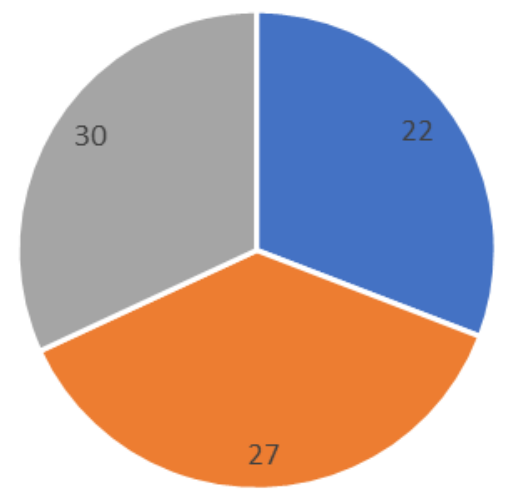

- hotel bintang $5 \quad$ - hotel bintang $4 \quad$ m hotel bintang $3 \quad$ m total 79 hotel

Gambar 1. Hotel Berbintang di Kawasan Pariwisata Ubud 
Pada sub bahasan selanjutnya akan dibahas secara detail identifikasi dan analisis pola persebaran hotel berbintang di Kawasan Pariwisata Ubud.

\section{A. Hotel Bintang Tiga}

Pada bagian ini akan digambarkan pemetaan hotel bintang tiga serta analisis pola persebarananya. Pola persebaran hotel bintang tiga diidentifikasi berdasarkan beberapa faktor penentu yang manjadi dasar pertimbangan antara lain, lokasi atau tata letak, akses masuk, dan potensi view atau pemandangan yang terletak di sekitar hotel. Berdsarkan observasi awal, isu-isu tersebut dianggap memberikan pengaruh yang segnifikan terhadap pola persebaran hotel bintang tiga di Kawasan Pariwisata Ubud. Untuk lebih jelasnya akan dijelaskan pada gambar tabel berikut.

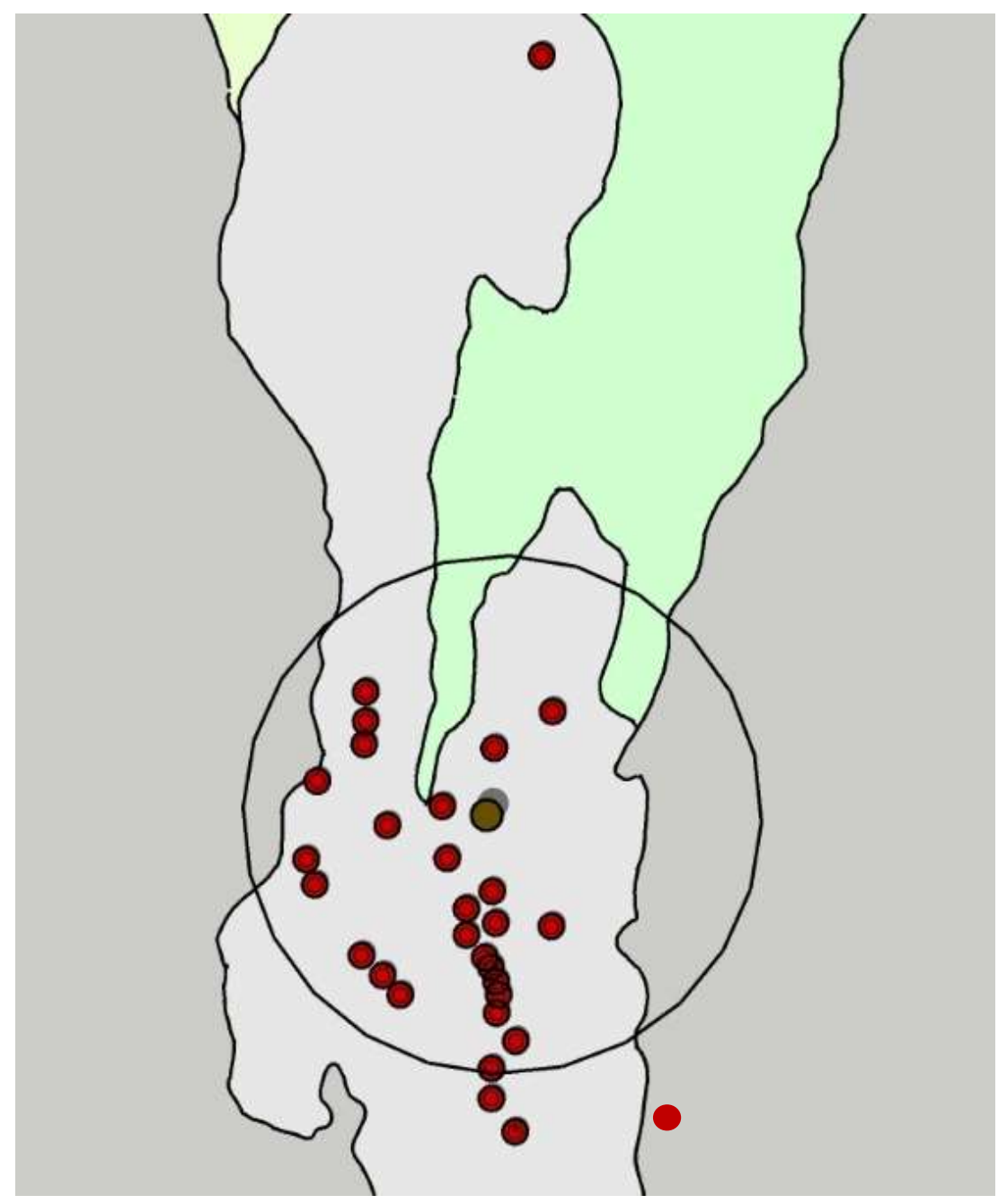

Gambar 2. Pola Persebaran Hotel Bintang Tiga di Kawasan Pariwisata Ubud

Berdasarkan gambar di atas dapat dilihat tata letak hotel bintang tiga yang cendrung membentuk pola berkelompok pada suatu area, dan juga pola linier yaitu mengikuti Jalan Monkey Forest menuju pusat Ubud. Sebagian besar hotel bintang tiga terletak di radius 2,5 km dari pusat Ubud, meskipun ada beberapa yang terletak jauh dari pusat Ubud. 
Untuk lebih jelasnya mengenai tata letak dan akses masuk hotel bintang tiga di Kawasan Pariwisata Ubud akan dijelaskan pada gambar berikut.

\section{hotel bintang tiga berdasarkan lokasi}

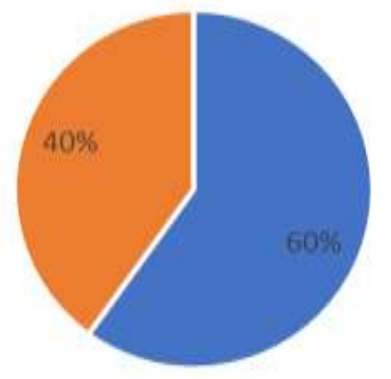

- pusat ubud = pinggir ubud

Gambar 3. Presentase Hotel Bintang Tiga Berdsarkan Lokasi

Dari data di atas dapat disimpulkan sebagian besar atau $60 \%$ hotel bintang tiga terletak dekat dengan pusat Ubud (Puri dan Pasar Ubud) dengan radius sekitar $2,5 \mathrm{~km}$. Sisanya $40 \%$ terletak di radius 2,5-6 km dari pusat Ubud. Lokasi tersebut dapat ditempuh hanya dengan berjalan kaki atau berkendara kurang dari 10 menit. Jadi dapat disimpulkan, hotel dengan kelas bintang tiga di Kawasan Pariwisata Ubud cendrung memilih lokasi dekat dengan pusat Ubud.

\section{hotel bintang tiga berdasarkan akses/jalan masuk}

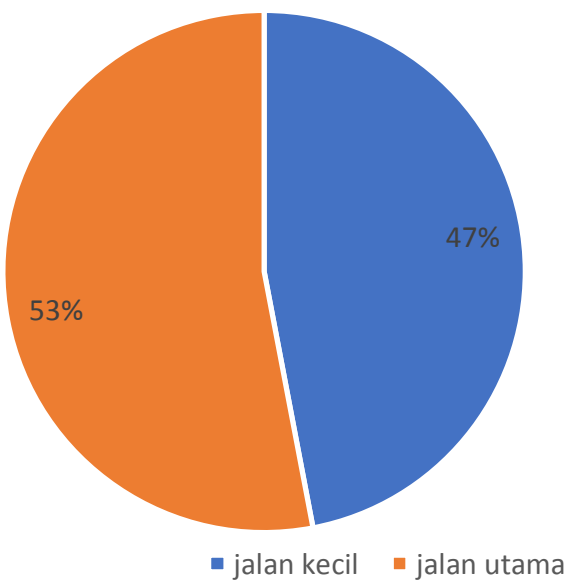

Gambar 4. Presentase Hotel Bintang Tiga Berdsarkan Akses/Jalan Masuk 
Ditinjau berdsarkan akses atau jalan masuknya, sebagian besar hotel bintang tiga di Kawasan pariwisata ubud memiliki atau berada di jalur utama. Jalan utama maksudnya adalah jalan yang memeliki lebar lebih dari 5 meter dan merupakan jalur padat wisata. Sisanya dengan presentase $47 \%$ mempunyai akses berupa jalan kecil. Jalan kecil maksudnya di sini adalah jalan dengan lebar kurang dari 5 meter dan bukan merupakan jalur utama wisata di Ubud. Selain tata letak dan akses masuk, pada bagian ini juga dianalisis faktor lain yang menjadi dasar pertimbangan pola persebaran hotel bintang tiga di Kawasan Pariwisata Ubud. Faktor tersebut adalah potensi pemandangan alam yang terletak disekitarnya. Untuk lebih detail akan dijelaskan pada gambar berikut.

\section{hotel bintang tiga berdasarkan view}

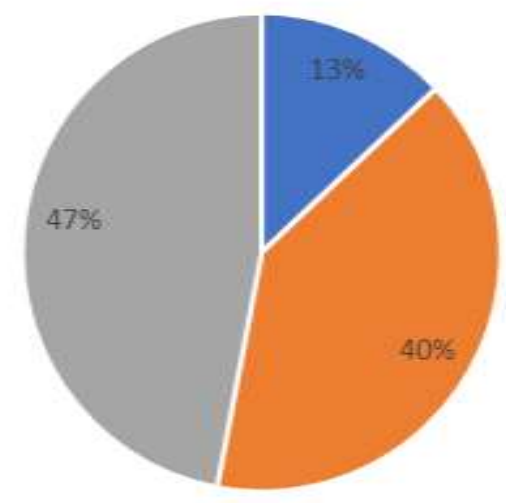

- tebing sungai = sawah = taman buatan

Gambar 5. Presentase Hotel Bintang Tiga Berdsarkan Potensi View

Berdasarkan data di atas dapat disimpulkan sebagian besar atau 47\% hotel bintang tiga memanfaatkan taman buatan atau tidak mendapatkan pemandangan alam langsung berupa tebing sungai atau sawah. Jadi pemandangan alam sekitar bukan merupakan faktor penentu utama dari pemilihan lokasi hotel bintang tiga di Kawasan Pariwisata Ubud.

\section{B. Hotel Bintang Empat}

Pada sub bahasan ini akan dianalisis pola persebaran hotel bintang empat berdasarkan faktor-faktor penentu yang manjadi dasar pertimbangan antara lain, lokasi atau tata letak, akses masuk, dan potensi view atau pemandangan yang terletak di sekitar hotel. 


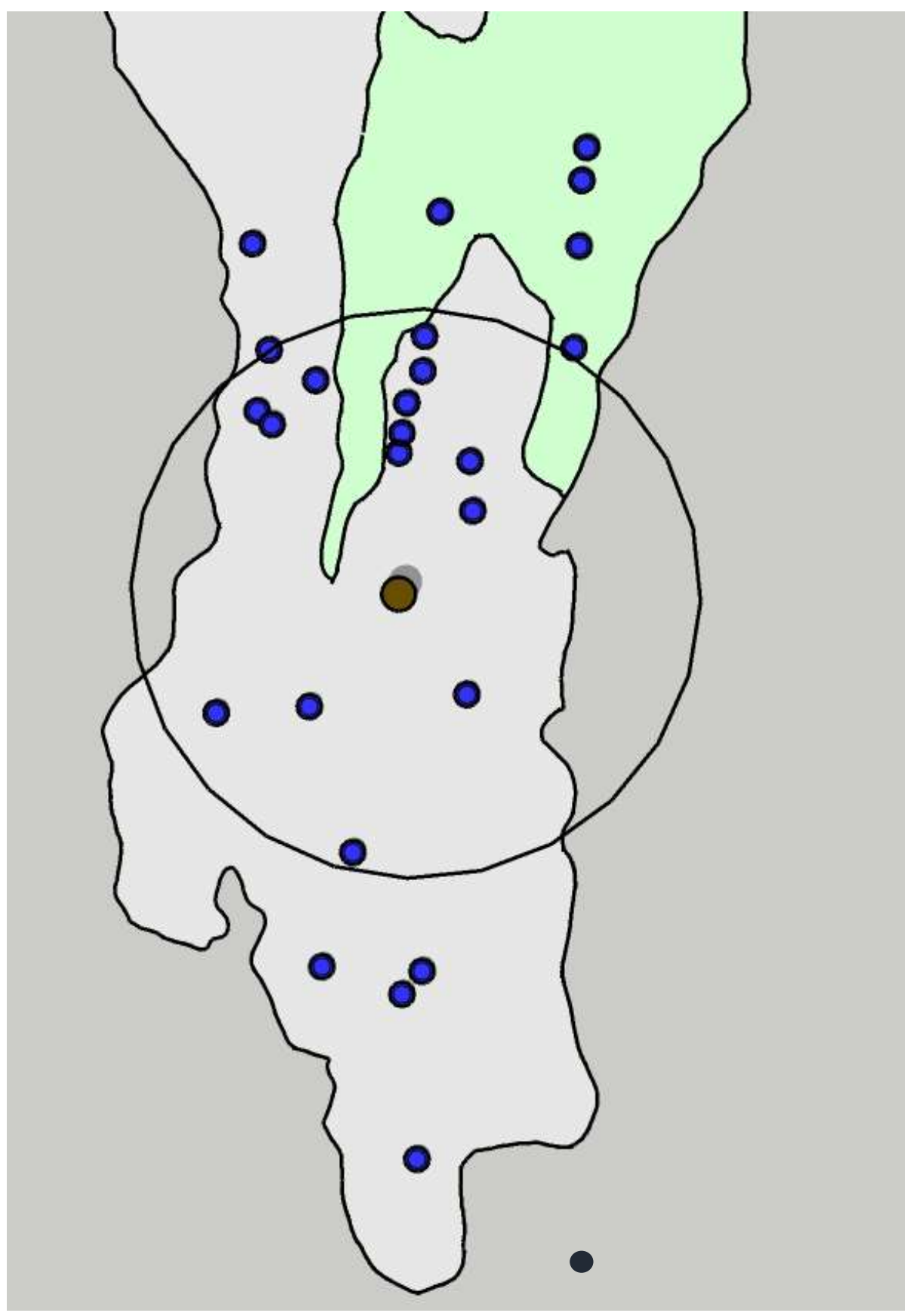

Gambar 6. Pola Persebaran Hotel Bintang Empat di Kawasan Pariwisata Ubud

Berdasarkan gambar diatas dapat dilihat tata letak hotel bintang empat yang cendrung membentuk pola menyebar ke area pinggiran Ubud. Di beberapa area juga terdapa pola linier yaitu mengikuti jalir utama dari Ubud menuju Kedewatan. Sebagian besar hotel bintang empat terletak di luar radius $2,5 \mathrm{~km}$ dari pusat Ubud, meskipun ada beberapa hotel bintang empat yang terletak dekat dengan pusat Ubud. Untuk lebih jelasnya mengenai tata letak dan akses masuk hotel bintang empat di Kawasan Pariwisata Ubud akan dijelaskan pada tabel berikut. 


\section{hotel bintang empat berdasarkan lokasi}

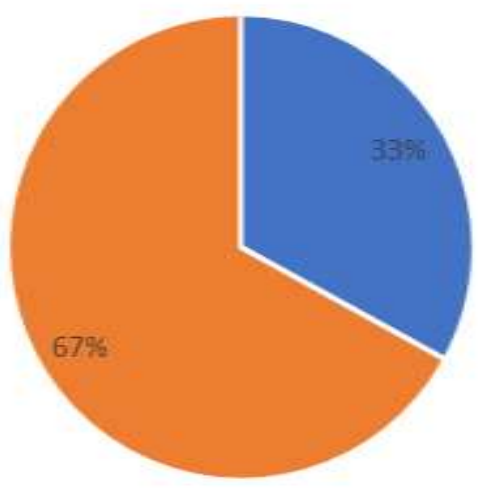

- pusat ubud = pinggir ubud

\section{Gambar 7. Presentase Hotel Bintang Empat Berdsarkan Lokasi}

Dari data dan di atas dapat disimpulkan sebagian besar atau $67 \%$ hotel bintang empat terletak dipinggir Ubud dengan radius lebih dari $2,5 \mathrm{~km}$. Sisanya $33 \%$ terletak di radius kurang dari $2,5 \mathrm{~km}$ dari pusat Ubud. Lokasi tersebut tidak dapat ditempuh dengan berjalan kaki. Jadi dapat disimpulkan, hotel dengan kelas bintang empat di Kawasan Pariwisata Ubud cendrung memilih lokasi pada area pinggiran atau jauh dari pusat Ubud

\section{hotel bintang empat berdasarkan akses/jalan masuk}

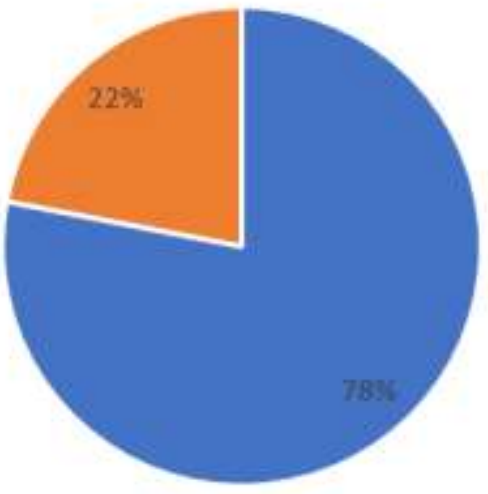

- jalan kecil = jalan utama

Gambar 8. Presentase Hotel Bintang Empat Berdsarkan Akses/Jalan Masuk 
Ditinjau berdsarkan akses atau jalan masuknya, sebagian besar atau $78 \%$ hotel bintang empat di Kawasan pariwisata ubud memiliki akses jalan kecil atau tidak terletak pada jalur utama. Jalan kecil maksudnya di sini adalah jalan dengan lebar kurang dari 5 meter dan bukan merupakan jalur utama menuju objek wisata. Sisanya $22 \%$ hotel bintang empat terletak pada jalan utama atau jalur padat kendaraan pariwisata. Selain tata letak dan akses masuk, pada sub bahasan ini juga dilakukan analisis faktor lain yang dapat menjadi dasar pertimbangan pola persebaran hotel bintang empat di Kawasan Pariwisata Ubud. Faktor tersebu adalah potensi pemandangan alam yang terletak disekitarnya. Untuk lebih detail akan dijelaskan pada tabel berikut.

\section{hotel bintang empat berdasarkan view}

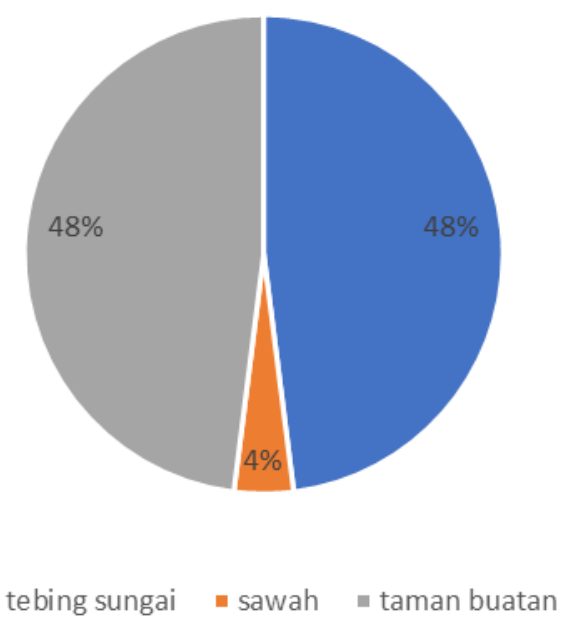

\section{Gambar 9. Presentase Hotel Bintang Empat Berdsarkan Potensi View}

Berdasarkan data di atas dapat disimpulkan hotel bintang empat dengan view tebing sungai dan taman buatan memiliki presentasi sama yaitu $48 \%$. Jadi apabila tidak terdapat potensi alam disekitar hotel maka akan dibuatkan taman buatan di dalam area hotel sebagai view utama. Berdsarkan data tersebut dapat disimpulkan ada atau tidaknya potensi view langsung seperti sungai dan sawah tidak menjadi faktor pertimbangan penting dalam pimilihan lokasi hotel bintang empat.

\section{Hotel Bintang Lima}

Hotel bintang lima adalah hotel dengan tingkat paling tinggi dan memiliki fasilitas dan pelayanan paling lengkap. Pada sub bab ini akan dianalisis pola persebaran hotel bintang lima berdasarkan faktor-faktor penentu yang manjadi dasar pertimbangan antara lain, lokasi atau tata letak, akses masuk, dan potensi view atau pemandangan yang terletak di sekitar hotel. 


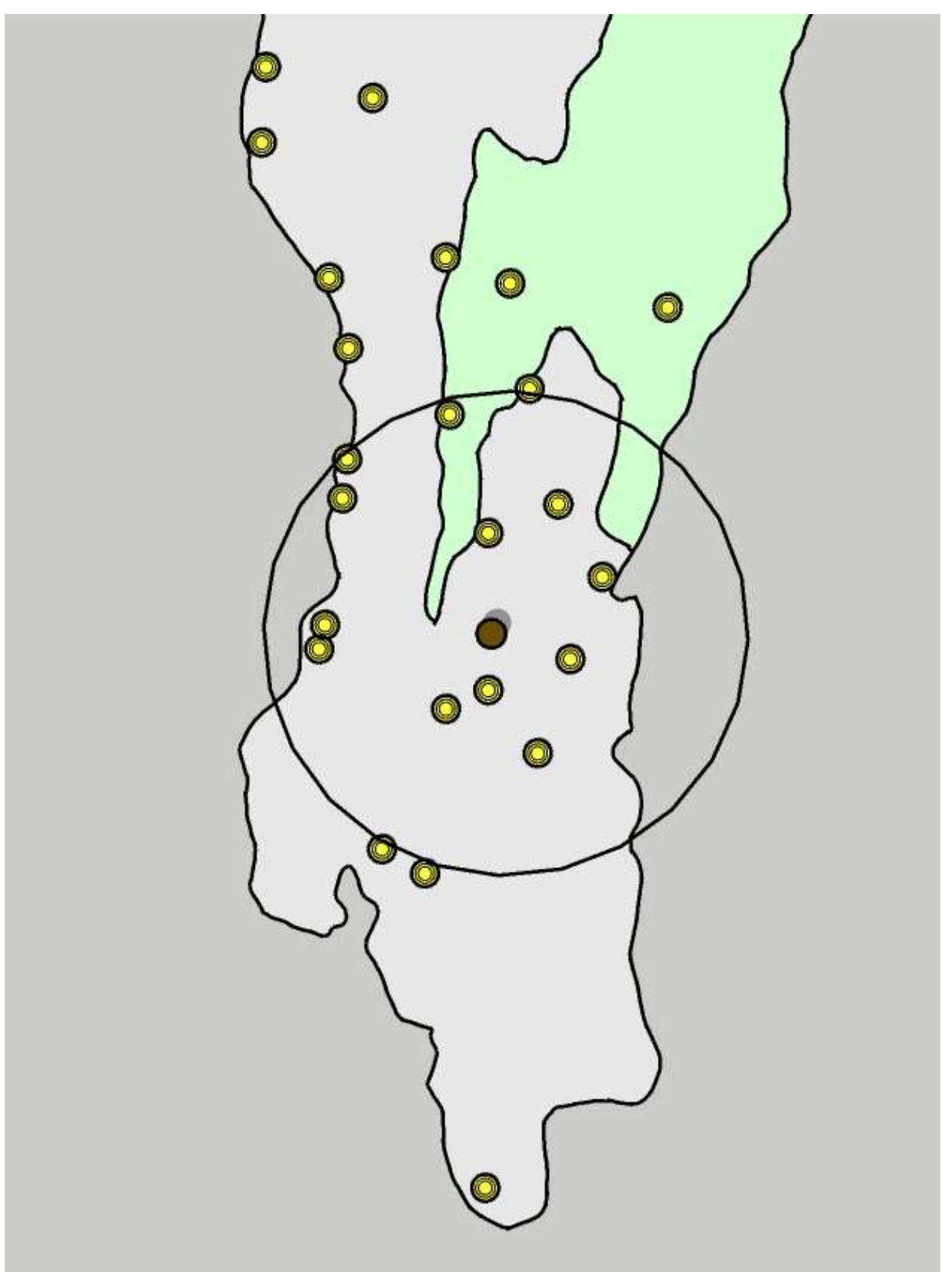

Gambar 10. Pola Persebaran Hotel Bintang Lima di Kawasan Pariwisata Ubud

Berdasarkan gambar diatas dapat dilihat tata letak hotel bintang lima yang cendrung membentuk pola menyebar. Berdasarkan tata letak lokasi, terdapat hotel bintang lima yang terletak dekat dengan pusat ubud (dalam radius $2,5 \mathrm{~km}$ ) dan ada juga yang terletak jauh dari pusat Ubud (diluar radius $2,5 \mathrm{~km}$ ). Jika diperhatikn dalam peta, tidak terlihat pola linier pada tata letak hotel bintang di Kawasan Pariwisata Ubud. Untuk lebih jelasnya mengenai tata letak dan akses masuk hotel bintang empat di Kawasan Pariwisata Ubud akan dijelaskan pada tabel berikut. 


\section{hotel bintang lima berdasarkan lokasi}

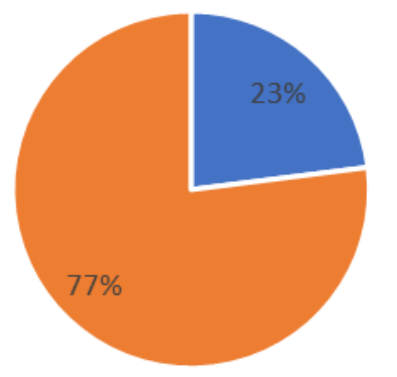

- pusat ubud " pinggir ubud

Gambar 11. Presentase Hotel Bintang Lima Berdsarkan Lokasi

Dari data dan di atas dapat dilihat sebagian besar atau $77 \%$ hotel bintang lima terletak pada area pinggiran Ubud dengan radius lebih dari $2,5 \mathrm{~km}$. Sisanya $23 \%$ terletak dalam radius kurang dari $2,5 \mathrm{~km}$ dari pusat Ubud. Lokasi tersebut tidak dapat ditempuh dengan berjalan kaki. Jadi dapat disimpulkan, hotel dengan kelas bintang lima di Kawasan Pariwisata Ubud cendrung memilih lokasi pada area pinggiran Ubud.

\section{hotel bintang lima berdasarkan akses/jalan masuk}

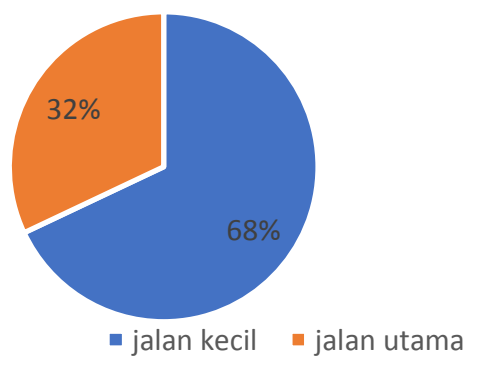

Gambar 12. Presentase Hotel Bintang Lima Berdsarkan Akses/Jalan Masuk

Ditinjau berdsarkan akses atau jalan masuknya, sebagian besar hotel bintang lima $(68 \%)$ memiliki akses jalan kecil yang tidak terletak pada jalur utama. Jalan kecil maksudnya di sini adalah jalan dengan lebar kurang dari 5 meter dan bukan merupakan jalur utama padat lalu lintas di Ubud. Sisanya $32 \%$ hotel bintang lima terletak pada jalan utama dengan aksibilitas tinggi akomodosi wisata. Selain tata letak dan akses masuk, pada sub bahasan ini juga dianalisis faktor lain yang dapat menjadi dasar pertimbangan pola persebaran hotel bintang lima di Kawasan Pariwisata Ubud. Faktor tersebut adalah 
potensi pemandangan alam yang terletak disekitarnya. Untuk lebih detail akan dijelaskan pada tabel berikut.

\section{hotel bintang lima berdasarkan view}

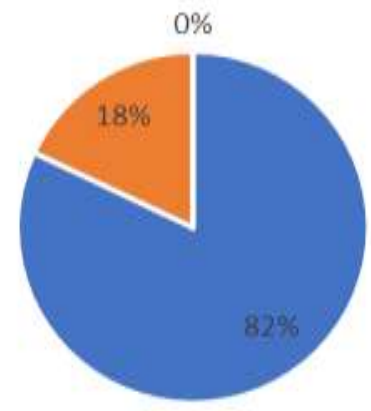

- tebing sungai = sawah = taman buatan

Gambar 13. Presentase Hotel Bintang Lima Berdsarkan Potensi View

Berdasarkan data di atas dapat dilihat semua hotel bintang lima di Kawasan Pariwisata Ubud mempunyai daya tarik view berupa hutang tebing sungai dan persawahan. Sebanyak $82 \%$ hotel bintang lima di Kawasan Pariwisata Ubud menawarkan view hutan tebing sungai, dan sisanya $18 \%$ menawarkan view persawahan. Tidak terdapat hotel bintang lima yang tidak mempunyai potensi pemandangan langsung alam terbuka di Kawasan Pariwisata Ubud. Jadi dapat disimpulkan potensi view menjadi salah satu faktor utama dalam pemilihan lokasi hotel bintang lima di Kawasan Pariwisata Ubud.

\section{Pola Persebaran Hotel Berbintang di Kawasan Pariwisata Ubud}

Terdapat beberapa pola persebaran hotel berbintang di Kawasan Pariwisata Ubud. Hotel bintang tiga cendrung membentuk pola berkelompok dan linier mengikuti jalan utama di pusat Ubud. Hotel bintang empat cendrung membentuk pola menyebar yang sebagian besar terletak di pinggiran Ubud. Hotel bintang lima juga memiliki pola menyebar dengan lokasi dekat pusat Ubud dan pinggiran Ubud. Hotel bintang empat dan hotel bintang tidak membentuk pola linier karena akses atau jalan utama bukan menjadi faktor penentu dari pemilihan lokasinya. Faktor pertimbangan utama dari hotel bintang empat dan bintang lima adalah potensi alam yang akan dijadikan daya tarik utama selain kelengkapan fasilitasnya. Pola persebaran hotel berbintang di Kawasan Pariwisata Ubud dapa digambarkan sebagai berikut. 


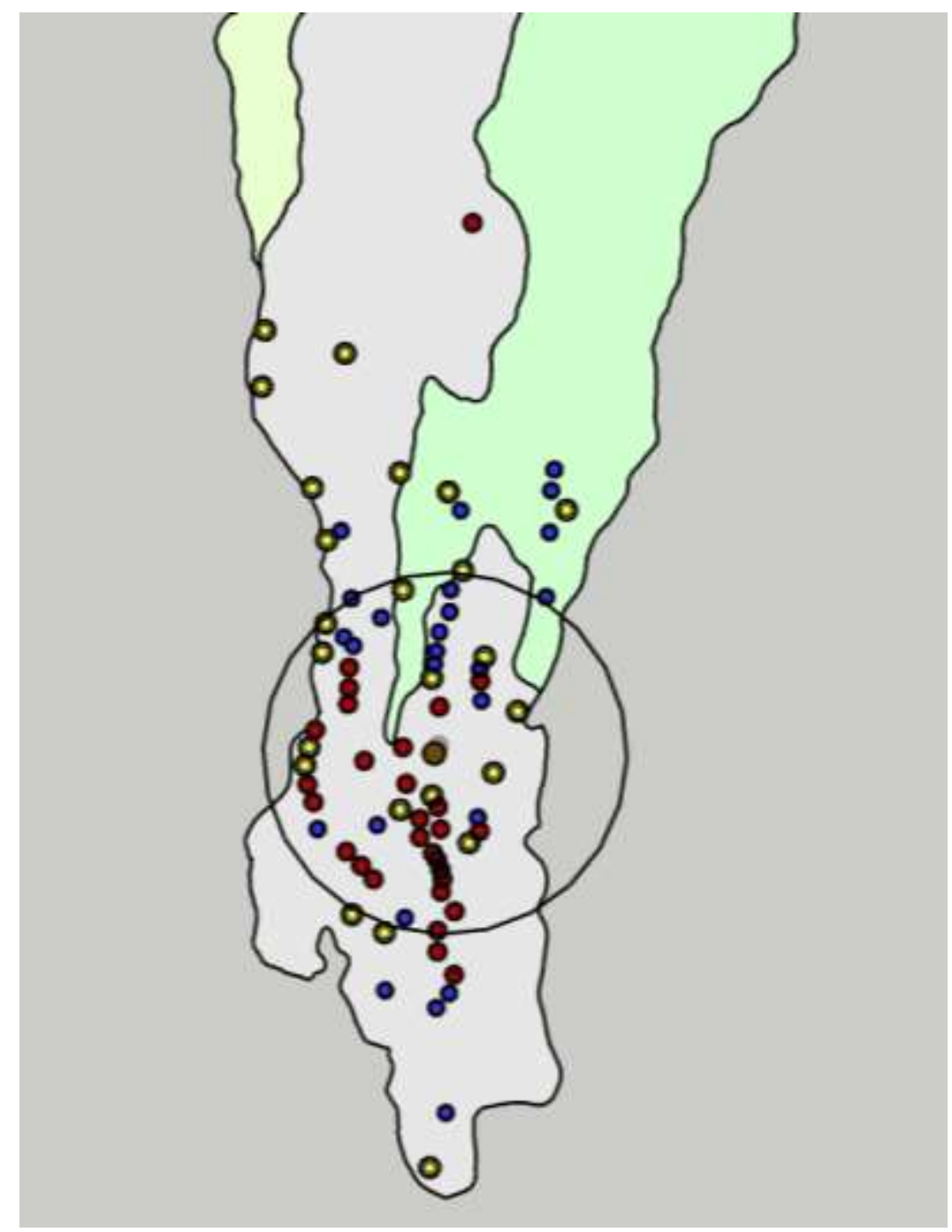

Gambar 14. Pola Persebaran Hotel Berbintang di Kawasan Pariwisata Ubud

Berdasarkan analisis data yang dilakukan pada bab sebelumnya, karakteristik pola persebaran Hotel Berbintang di Kawasan Pariwisata Ubud dapat disimpulkan pada tabel berikut.

Tabel 4. Karakteristik Pola Persebaran Hotel Berbintang di Kawasan Pariwisata Ubud

\begin{tabular}{|l|l|l|l|c|c|c|c|c|}
\hline No & $\begin{array}{l}\text { Kelas } \\
\text { Hotel }\end{array}$ & \multicolumn{2}{|c|}{ Lokasi } & \multicolumn{2}{c|}{ Akses } & \multicolumn{3}{c|}{ View } \\
\cline { 2 - 8 } & $\begin{array}{l}\text { Ubud } \\
\text { Ubut }\end{array}$ & $\begin{array}{l}\text { Pinggir } \\
\text { Ubud }\end{array}$ & $\begin{array}{l}\text { Jalan } \\
\text { Kecil }\end{array}$ & $\begin{array}{l}\text { Jalan } \\
\text { Utama }\end{array}$ & $\begin{array}{l}\text { Tebing } \\
\text { Sungai }\end{array}$ & Sawah & $\begin{array}{l}\text { Taman } \\
\text { Buatan }\end{array}$ \\
\hline 2 & $\begin{array}{l}\text { Hotel } \\
\text { Bintang 3 }\end{array}$ & 0 & & & 0 & & & 0 \\
\hline 3 & $\begin{array}{l}\text { Hotel } \\
\text { Bintang 4 }\end{array}$ & & 0 & 0 & & & 0 & 0 \\
\hline
\end{tabular}


Berdasarkan data di atas dapat disimpulkan beberapa faktor yang mempengaruhi pola persebaran hotel berbintang di Kawasan Pariwisata Ubud antara lain.

\section{- Lokasi}

Untuk hotel dengan kelas bintang tiga pemilihan lokasinya cendrung berada di pusat Ubud atau dalam radius 2,5 km dari Puri/Pasar Ubud. Untuk Hotel dengan kelas bintang empat dan bintang lima pemilihan lokasinya lebih banyak di area pinggiran Ubud atau di luar dari radius $2,5 \mathrm{~km}$ dari pusat Ubud.

\section{- Akses}

Terdapat temuan menarik terkait akses atau jalan menuju ke lokasi resort di Kawasan Pariwisata Ubud. Hotel bintang empat dan hotel bintang sebagian besar hanya memilik akses atau jalan masuk dengan lebar kurang dari 5 meter dan tidak terletak pada jalur utama menuju objek wisata di Kawasan Pariwisata Ubud. Hotel bintang tiga cendrung mempunyai akses jalan dengan lebar lebih dari 5 meter dan terletak pada jalur pada kendaraan menuju objek wisata di Kawasan Pariwisata Ubud.

\section{- Potensi View}

Potensi pemandang alami berupa hutan tebing sungai dan perswahan adalah faktor utama dalam pemilihan lokasi hotel bintang lima dan bintang empat. Pada penelitian ini juga ditemukan bahwa $48 \%$ hotel bintang empat tidak mempunyai potensi alam hutann tebing sungai dan persawahan atau hanya menawarkan pemandangan taman buatan pada area hotel. Hotel bintang tiga sebagian besar menawarkan pemandangan dengan taman buatan di alam area hotel. Tetapi terdapat juga $40 \%$ hotel bintang tigas dengan pemandang persawahan hijau. Potensi view di sekitar area hotel bukan faktor penentu utama dalam pimilihan lokasi hotel bintang tiga.

\section{Kesimpulan}

Berdasarkan data dan analisis yang dilakukan pada bab sebelumnya dapat ditarik beberapa kesimpulan pada penelitian tahap satu ini antara lain, (1) kecendrungan pola persebaran hotel berbintang di Kawasan Pariwisata Ubud berbeda-beda tergantung pada kelasnya, hotel bintang tiga cendrung membentuk pola linier dan berkelompok di Pusat Ubud, sedangkan hotel bintang empat dan bintang lima cendrung membentuk pola menyebar di area pinggiran Ubud. (b) Faktor-faktor yang berpengaruh dalam pola persebaran hotel berbintang di Kawasan Pariwisata Ubud antara lain, akses dan potensi pemandangan alam. Hotel bintang tiga lebih mengutamakan akses sedangkan hotel bintang empat dan bintang lima lebih mengutamakan potensi pemandangan alam. (c) Fasilitas yang ditawarkan hotel berbintang di Kawasan Pariwisata Ubud sudah sesuai dengan standar yang berlaku, tetapi jika ditinjau dari jumlah kamarnya tidak sesuai dengan standar hotel berbintang. 


\section{Saran}

Berdsarkan hasil temuan diharapkan pemerintah dapat mempertegas peraturan terkait perijinan hotel berbintang di Kawasan Pariwisata Ubud, melihat pola persebaran hotel resort yang cendrung memilih lokasi lahan hijau seperti area tebing sungai dan persawahan. Untuk peneliti lebih lanjut diharapkan nanti dapat meneliti dampak yang ditimbulkan pembangunan hotel resort berbintang terhadap lingkungan sekitar di Kawasan Pariwisata Ubud

\section{DAFTAR PUSTAKA}

Fonny.T,C. 2008. "Analisa strategi prospektor dan strategi bertahan yang digunakan oleh Hotel Lombok Raya di Mataram”. tesis. Nusa Tenggara Barat : Universitas Petra.

Lawson, Fred. 1995. Hotels \& Resorts Planning, Design And Refurbisment, Oxford : Butterworth Architecture.

Moleong, L. J.1989. Teori Penelitian Kualitatif.

Picard, M. 2006. Bali : Pariwisata Budaya dan Budaya Pariwisata. Jakarta: Gramedia

Putra, I.D.G. 2013. "Pemanfaatan Lahan Hunian Untuk Aktivitas Komersial Rumah Tangga Di Lingkungan Permukiman Padangtegal Tengah, Ubud ".tesis. Denpasar: Universitas Udayana

Sukawati,.T.O.A A. 2008. "Perubahan Spasial Desa Adat Ubud, Gianyar, Bali, dalam Era Globalisasi : Sebuah Kajian Budaya" (disertasi). Denpasar : Universitas Udayana 